\title{
Manufacturing Pre-Decisions: A Comparative Analysis of Environmental Impact Statement (EIS) Reviews in Brazil and Portugal
}

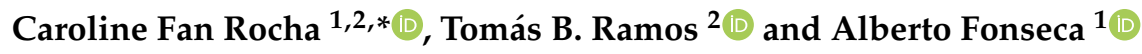 \\ 1 Graduate Program in Environmental Engineering, Federal University of Ouro Preto, Ouro Preto 35400-000, \\ Brazil; alberto@ufop.edu.br \\ 2 CENSE-Center for Environmental and Sustainability Research, NOVA School of Science and Technology, \\ NOVA University Lisbon, 2829-516 Lisbon, Portugal; tabr@fct.unl.pt \\ * Correspondence: caroline.fanrocha@gmail.com
}

Received: 19 May 2019; Accepted: 8 June 2019; Published: 12 June 2019

\begin{abstract}
The review of environmental impact statements (EIS), despite its relevance to impact assessment effectiveness, has received scarce scholarly attention. Few studies have gone beyond the realm of regulatory evaluations to understand the managerial meanders of the review process. This study evaluated the responsibilities, procedures, information inputs, and scope of EIS reviews within two environmental authorities: APA (Portuguese Environment Agency), in Portugal, and SEMAD (State Secretariat for Environment and Sustainable Development), in the Brazilian state of Minas Gerais. Based on a qualitative multiple-case study methodology informed by participant observation, unstructured interviews, and content analysis of 12 EIS review reports, the study provided what is arguably one of the most detailed characterizations of EIS review to date. While following similar institutional arrangements and broad procedural steps, the EIS review has important differences in APA and SEMAD. Overall, the Portuguese agency was found to have a more structured, participative, interdisciplinary, detailed, and grounded review, thus meeting some of the good practices often cited in the literature. The EIS review reports prepared by APA reviewers were also found to provide a profoundly more complete and transparent account of the review process. The details of the review process revealed in the article can affect perceptions around the legitimacy and reliability of reviewers' recommendations.
\end{abstract}

Keywords: environmental impact assessment (EIA); review stage; environmental impact statement (EIS); EIS review; public administration; Portugal; Brazil

\section{Introduction}

Among the world's most influential environmental policy tools is environmental impact assessment (EIA) [1]. This decision-making process, which tries to predict the future consequences of a current or proposed action [2], was first regulated in the United States in 1969 but spread to almost every country on Earth. Economic development and environmental conservation worldwide are routinely affected by EIA decisions [3]. The growing importance of EIA has driven the emergence of a vast body of research since the 1970s. Dissertations, theses, scientific books, and articles have long been addressing EIA's challenges. However, some intricate aspects of this decision-making process, such as public authorities' review of environmental impact statements or studies (EIS), have received marginal attention so far. As noted by Morgan [4] in his review of the state of the art of EIA, in the past decades, scholars have devoted significant attention to theoretical and effectiveness issues, particularly in connection with some of EIA's main stages, such as screening, scoping, impact prediction, significance, monitoring, 
and follow-up. The prioritization of particular EIA stages has also been found in other reviews of EIA's knowledge gaps [5-10].

EIS review, that is, the administrative stage in which public authorities review EISs and other pieces of information, has long been investigated, but mainly through the lenses of content quality. For decades, practitioners and policy-makers have been concerned about what contents should be included or not in EISs so that informed decisions can be made [11-15]. While there have been studies targeting specific aspects of the review process, such as the role of external stakeholders [16], advantages and disadvantages of individuals versus group reviews [17], and knowledge management [18,19], among others, there is still a scarcity of in-depth empirical research on how authorities review EISs.

The scarcity of empirical information on the public administration of EIS reviews is a problem, because the intricacies of this stage directly affect EIA decisions. Despite its various technical and scientific facets, EIA has a strong political dimension [20] that deals with high dosages of uncertainty, value-laden trade-offs, and subjectivity. These 'fuzzy' elements of the decision-making process are to a great extent judged in the review stage. Sense-making around what should be a good or bad decision is to a great extent 'manufactured' in the review process [21]. Thus, understanding how this stage works is a fundamental step towards the promotion of more transparent, legitimate, and efficient EIAs.

The main objective of this study was to explore three administrative traits of EIS review in the empirical context of Brazil and Portugal: (1) responsibility and profile of reviewers; (2) procedures and information inputs; and (3) scope of review reports. More specifically, this article critically and comparatively explored how the national Portuguese environmental agency, APA (Portuguese acronym of Portuguese Environment Agency), and the Minas Gerais State environmental agency, SEMAD (acronym of State Secretariat for Environment and Sustainable Development) manage the review of EISs. In light of this analysis, a number of recommendations are made as to how EIS reviews can be enhanced to deliver more substantive and procedural results. The research focuses on two very different empirical contexts (i.e., national agency in a developed country versus state agency in a developing country) to capture a more diverse picture of current EIS review practices.

This study was structured in five sections. The next one reviews some of the key approaches to EIS review. The methodology is explained in Section 3. Section 4 presents and discusses the findings. Finally, Section 5 draws concluding remarks.

\section{EIS Review Approaches}

The world's diverse EIA legislations and institutional arrangements have long been inspiring cross-country and within-country comparisons of EIA systems [6,22-24]. While this literature has been showing many approaches to EIS review, Ross [25] has long noted that this stage is mainly concerned with three key areas of inquiry: (1) whether EIS focuses on key issues (compliance with Terms of References and expected assessment scope); (2) whether information in EIS is scientifically and technically sound; and (3) whether EIS can be clearly understood by decision makers. This 'quality assurance' facet of the EIS review stage, mirrored in IAIA's best practice principles [26], is arguably the most common in worldwide practice. Nevertheless, quality assurance can be carried out under different formal and informal institutional arrangements [27]. For example, the EIS review can be an internal responsibility of the proponent agency, or carried out by environmental authorities, interagency technical groups, independent review panels, or permanent commissions. The use of external independent reviewers based on review panels or permanent commissions, while common in countries like Canada and the Netherlands, is uncommon worldwide. As noted by NCEA [28] (p. 2)., "( . . ) in most countries, review is the responsibility of the competent authority on EIA or the competent authority for decision-making on a proposed project".

The procedures and outcomes of reviews can also vary substantially. For example, Wood [6] in his comparison of EIS review in the United States, the UK, The Netherlands, Canada, Australia, and New Zealand, realized that EISs are not always publicly reviewed; moreover, proponents do not always need to respond to the points raised by authorities. Across the diverse practices of Australian 
provinces, EIS reviews tend to go beyond quality verification to include public consultations and the issuing of a decision recommendation for agencies in charge of decision making and approvals [29]. These recommendations, as highlighted by Thomas and Elliot [30], are actually 'advice', as authorities are not required to adopt them. In the UK, according to Glasson et al. [31], EIS review also aims to "advise on whether a project should be allowed to proceed", although this is not mandatory. The main generic steps of the review process have been outlined by Sadler [27] (p. 124) as follows:

1. Identify deficiencies in the EIA report using reference materials;

2. Determine shortcomings that are crucial to restricting informed decision making, separate these from the less important deficiencies, and focus primarily on the former in the review; and

3. Recommend to the responsible authority how and when any serious shortcomings should be remedied to assist decision making.

Some EIA capacity-building programs, like the one prepared by the International Institute for Environment and Development (IIED) for Tanzania, prescribe particular 'good practice' criteria for the EIS review stage, such as: seeking independent opinion, following content guidelines, holding public hearings and consultations, empowering reviewers to request additional information and, eventually, rejecting EISs on grounds of inadequacy [32]. Judging, however, which procedural or institutional approach is the best in a particular jurisdiction is a delicate task, because the effectiveness of each approach can be context-dependent. Particularly, the strengths of a country's EIS review process may not work elsewhere as expected [33].

In any case, the success of the review process is tightly related to the capacity of reviewers to judge whether EISs and other sources of information meet both legal and technical requirements, as well as whether further information should be provided. For this purpose, structured reviewing guidelines or checklists have long been perceived to be helpful [34]. However, such checklists, as mentioned in the previous section, are often concerned with the scope and quality of content and communication, overlooking managerial issues like effectiveness of procedures, information channels, and stakeholder responsibilities. Moreover, reviewers' roles in providing advice to authorities about whether or not a project should proceed still remain an area of limited guidance.

\section{Methodological Approach}

The scarcity of empirical studies on EIS review stems in part from the scarcity of easily accessible data related to this stage. Mere reviews of legislation, which is a common analytical choice in comparative EIA policy studies, can only capture broad traits of the review process because, as noted by Glasson, Therivel, and Chadwick [31], many administrative decisions are not mandatory and can only be understood by those who are directly involved in the system. To overcome such data barriers, this study adopted a qualitative multiple-case study approach informed by participant observation, unstructured interviews, and content analysis of internal review documents.

Among the many reasons why scholars decide to adopt qualitative methodological approaches is because they want to "engage in the complex, time-consuming process of data analysis through the ambitious task of sorting through large amounts of data and reducing them to a few themes or categories" [35] (p. 41). This reason is certainly reflected here, as this study aimed at capturing not only formal procedures, but mainly the vast amount of informal and publicly unavailable practices that occurs in the daily administrative routine of EIA authorities.

\subsection{Case Studies}

This research, while focusing on the empirical context of Brazil and Portugal, falls into the category called by Yin [36] as a multiple-case study. Data were collected in SEMAD, the Brazilian Minas Gerais State Environmental Agency, and in APA, the Portuguese Environmental Agency. While more time-consuming, multiple cases tend to be more compelling insofar as their contrasting findings provide a more robust basis for interpreting social phenomenon. The selection of these two cases was 
supported by the following criteria: (i) addressing distinctive EIA legal and institutional frameworks; (ii) covering different EIS reviewing systems; (iii) covering different geographic and socio-economic contexts; and (iv) covering countries with the same national official language and common cultural aspects, allowing an easier cross-comparison between the documents and data analyzed. In addition, the two cases were purposefully selected not only because they are convenient, as the co-authors of this study speak Portuguese and have contacts in both the Brazilian and Portuguese authorities, but mainly because they represent very different points in the spectrum of EIA systems. Both agencies are well-established institutions with decades of experience in EIS review. However, SEMAD is a subnational environmental authority in a developing country and APA is a national environmental authority in a developed country within the European Union. Such contrasting geographic and socioeconomic contexts are expected to enrich the discussions and generate more valuable lessons to scholars and practitioners worldwide.

\subsection{Participant Observation and Interviews}

Participant observation is " $(. .$.$) a method of data collection in which the researcher takes part in$ everyday activities related to an area of social life in order to study an aspect of that life through the observation of events in their natural contexts." [37] (p. 599). Some scholars, like Babbie [38], refer to this method as 'field work', because participants not always 'participate' on what they are researching. Regardless of the terminology, this study conducted 'participant observation' in SEMAD and APA to characterize internal procedures and information inputs. Given the lack of published material about this, the observation of review administration was fundamental to generate the data presented further below. During these observations, a number of clarifying, unstructured interviews were carried out with both SEMAD and APA staff. In July 2018, one of the co-authors of this article systematically observed the procedures and information inputs in SEMAD. The same systematic observation was carried out earlier in APA, in January 2017, when the same co-author was granted access to observe the reviewing practices of the Portuguese agency and conduct a number of interviews with internal staff.

\subsection{Content Analysis}

EIS review reports are arguably the most important documental evidence of the review process. This document, which may or may not be publicly available, presents the outcomes of the review process and eventual recommendations. EIS review reports were classified as 'knowledge repositories' for environmental agencies, as their contents can drive institutional learning [19]. An arbitrary sample of 12 EIS review reports was analyzed: 6 from SEMAD and 6 from APA, as presented in Table 1. The choice of a non-probabilistic sample was deemed appropriate because of the exploratory nature of the research [38].

While EIS content checklists abound in the EIA literature [15], content checklists for review reports are rare. Scholars have mostly been concerned with what is inside EISs, rather than with what is communicated in Review Reports. This study had to create a unique checklist with 15 criteria to guide the content analysis. These criteria were arbitrarily chosen by authors to enable an understanding of the following aspects of the review process: participation, procedures, methods, scope or reach, and recommendations. The analyzed items were judged as 'explicit' or 'not explicit'. Findings of the content analysis, presented further on in Table 2, were counted as 1, when explicit, or 0, when nonexplicit. Moreover, counts were aggregated to understand what contents are most often disclosed within and across environmental authorities.

The review reports, combined, had a total of 942 pages, which were systematically analyzed against the checklist of 15 criteria. Findings from the content analysis, following methodological good practice [39], were systematically organized in spreadsheet software to facilitate the identification of patterns and relevant information. 
Table 1. Sample of EIS review reports analyzed in the study.

\begin{tabular}{|c|c|c|c|c|c|c|}
\hline Jurisdiction & $\begin{array}{l}\text { Document } \\
\text { Code }\end{array}$ & Project Typology & $\begin{array}{c}\text { Number of } \\
\text { Reviewers } \\
\text { Explicit in EIS } \\
\text { Review Report }\end{array}$ & $\begin{array}{l}\text { Length of } \\
\text { EIS Review } \\
\text { Report } \\
\text { (in Pages) }\end{array}$ & $\begin{array}{c}\text { EIS Type } \\
\text { (Licensing } \\
\text { Type) }\end{array}$ & Publication \\
\hline \multirow{5}{*}{ Portugal } & PT-1 & Photovoltaic power plant & 9 & 81 & EIA/RNT & $\begin{array}{l}\text { December } \\
2018\end{array}$ \\
\hline & PT-2 & Hydraulic circuit & 10 & 145 & EIA/RNT & $\begin{array}{c}\text { August } \\
2018\end{array}$ \\
\hline & PT-3 & Accessibility of sea port & 11 & 151 & EIA/RNT & July 2018 \\
\hline & PT-4 & Modernization of railway & 9 & 263 & EIA/RNT & April 2018 \\
\hline & PT-5 & Extraction of limestone & 10 & 90 & EIA/RNT & $\begin{array}{l}\text { March } \\
2018\end{array}$ \\
\hline \multirow{7}{*}{$\begin{array}{l}\text { Minas } \\
\text { Gerais } \\
\text { (Brazil) }\end{array}$} & PT-6 & Resin factory & 11 & 59 & EIA/RNT & $\begin{array}{l}\text { February } \\
2018\end{array}$ \\
\hline & MG-1 & Sugar factory & 5 & 39 & EIA/RIMA & July 2018 \\
\hline & MG-2 & Small hydropower plant & 2 & 21 & $\begin{array}{l}\text { EIA/RIMA } \\
\text { e PCA }\end{array}$ & May 2018 \\
\hline & MG-3 & Thermoelectric plant & 3 & 40 & EIA/RIMA & $\begin{array}{c}\text { January } \\
2018\end{array}$ \\
\hline & MG-4 & $\begin{array}{l}\text { Extraction of sand and } \\
\text { gravel }\end{array}$ & 3 & 23 & RCA/PCA & $\begin{array}{l}\text { September } \\
2018\end{array}$ \\
\hline & MG-5 & Furniture factory & 4 & 22 & RCA/PCA & July 2018 \\
\hline & MG-6 & Metallurgy & 3 & 8 & RCA/PCA & $\begin{array}{c}\text { March } \\
2018\end{array}$ \\
\hline
\end{tabular}

\section{Results and Discussions}

\subsection{Institutional and Regulatory Frameworks of the EIA Systems in Brazil and Portugal}

SEMAD, the Brazilian state agency, has jurisdiction over a larger and more populated area when compared to APA. The territory of the Brazilian state of Minas Gerais $\left(586,522 \mathrm{~km}^{2}\right)$ is more than 6 times larger than Portugal's $\left(92,256 \mathrm{~km}^{2}\right)$, and its population ( 21 million) is about twice the population of Portugal ( 10.5 million). However, the EIA processes of SEMAD and APA are difficult to compare with simple numbers, because these processes are implemented in very different institutional and regulatory contexts.

In Portugal, EIA was defined as one of the policy tools of the Base Law of the Environment, initially established by the Law 11/1987, 7th of April, which specified requirements for the minimum contents of Environmental Impact Statements (Art. 31), and recently updated by the Law 19/2014, 14th of Abril. Yet the legal regime for EIA was formally approved 3 years later, through the transposition of the European Union Directive 85/337/EEU to the Portuguese legislation through Decree-Law (DL) 186/90, 6th of June. In recent years, EIA in Portugal was mainly legislated by Decree-Law (DL) 151-B/2013, 31st of October, which transposed the European Union Directive 2011/92/EU [40]. More recently, the DL 152-B/2017, 11th of December, transposed the revised European Union Directive 2014/52/EU, which, among other things, pushed member states' EIA processes to address issues such as climate change and also required EIA processes to ensure that EIS preparation and review are carried out by people with sufficient expertise [41].

Portugal has today a typical EIA process structured in the following stages: screening, scoping, elaboration of impact assessment studies, review, decision making, and follow-up. EIA can be triggered by both private and public projects that are likely to have significant environmental impacts. Screening lists determines which projects are subject to EIA.

The EIS Review stage in the Portuguese EIA process is to a large extent shaped by Arts. 9, 12, 13, $14,15,16$ of the DL 151-B/2013 and the DL 152-B/2017 revision, which established minimum content requirements for EISs, as well as a revision procedure carried out by an interdisciplinary evaluation committee (EC) led by the EIA authority but with participants from various public institutions related to the effects of the project. The EC is responsible for verifying the conformity of the EIS document and publishing its findings in a technical review document that will inform a final decision by the EIA 
authority. This decision is known as the 'Declaration of Environmental Impact', whose Portuguese acronym is DIA. The decision can be favorable, favorable with conditions, or unfavorable.

The EIA system coordinated by SEMAD in the Brazilian state of Minas Gerais is embedded within the country's federal legislation. EIA first emerged in Brazil in the 1970s driven by the World Bank and embryonic state legislation in São Paulo and Rio de Janeiro [42,43]. However, it only started to become a widespread practice in the late 1980s, after federal legislation [44] and regulations made EIA mandatory for both public and private projects. EIA was even included in Article 225 of the 1988 Brazilian constitution, which requires potentially environmentally harmful construction works and activities to prepare 'prior environmental impact studies'.

The main requirements for EIA in Brazil are set by the National Council on the Environment Resolution 01/1986, whose Portuguese acronym is CONAMA [45]. This resolution exemplifies a list of projects that should be subject to EIA and establishes minimum content requirements for EISs. In the 1990s, CONAMA Resolution 237/1997 [46] further regulated the link between EIA and Brazil's three-phased environmental licensing system and also provided incentives for the creation of simplified impact assessment studies at the federal, state, and municipal levels. As recently noted by Fonseca and Rodrigues [47], it is difficult to generalize the traits of the Brazilian EIA system, because administrative procedures and EIS documents can vary substantially within and across jurisdictions.

In the Minas Gerais state, EIA was regulated in 1990 by the Normative Deliberation (known by the acronym DN) 01/1990 of the State Council for Environmental Policy (COPAM). This regulation was later revised by DN COPAM 74/2004 and, more recently, by DN COPAM 217/2017. The latter established an EIA system that is confusingly embedded in the licensing procedure. Unlike the Portuguese legislation and other Brazilian states like São Paulo, in Minas Gerais, there is neither an explicit definition of EIA nor a list of projects that are subject to EIAs. While the state adopts a risk assessment approach in the screening stage to classify projects and determine likely studies, the decision as to which projects are subject to EIA is discretionary. Projects can be subject to EIA not only in the planning and feasibility phases, but also during the operation phase, when the project has already been constructed on the ground and is in full operation. For the latter, the state created 'correction environmental licenses' to give an opportunity for incompliant enterprises to go through EIA. The general rule in Minas Gerais is that a project can only be implemented after completing the EIA process and being granted a license. However, given the high degrees of noncompliance with environmental laws in that state [48], SEMAD created 'corrective licenses' to give an opportunity for illegal development projects to go through ex-post impact assessments and enhance their environmental performance.

The impact assessment studies required in either the feasibility or construction and operation phases of projects in Minas Gerais can be comprehensive (whose Portuguese acronym is EIA/RIMA) or simplified (e.g., RCAs). The coordination of the EIA process is carried out by SEMAD's regional branches, known as SUPRAMs (Portuguese acronym of Regional State Environmental Offices), which are also in charge of the decision making of less impactful projects. Decisions on high-class projects are carried out by COPAM, a collegiate forum, whose final decision can be approved, approved with conditions or denied. Moreover, unlike the Portuguese EIA system, in Minas Gerais, the EIS review stage is not explicitly addressed in regulations. Review procedures and responsibilities are designed and implemented at the discretion of civil servants and elected administrations. This study, however, shed light on how discretion has been implemented in practice.

\subsection{EIS Review's Responsibilities in Portugal and Minas Gerais}

As introduced in Section 2, the EIA literature has been recurrently concerned with the issue of responsibility in EIS review, particularly of 'institutional' responsibility, that is, which institutions are involved in the review and what their roles and powers are. The legislation and participant observations revealed that, in general, the dynamics of institutional responsibility are somewhat similar in the Portuguese and Minas Gerais' EIA processes. In both countries, EIA is triggered by the need to obtain a declaration or license that authorizes project implementation. In both countries, 
EISs are prepared by proponents (which can hire private consultancies) and later reviewed by an environmental authority. Decision making is also a competence of environmental authorities, i.e., APA and SEMAD. A subtle difference, however, is that SEMAD, in addition to being the environmental authority, is also, and always, the licensing authority; whereas in Portugal, there is a wide range of government agencies and bodies that can function as licensing authorities. In most cases, APA is only the environmental authority.

Despite these broad institutional similarities, SEMAD and APA have different approaches to managing the responsibilities of people involved in EIS reviews. As presented in the previous section, Portugal has a more inclusive and participative approach to conducting the review: EISs are reviewed by an evaluation committee that, as mandated by law, must include reviewers from various external public organizations whose knowledge areas are related to the project. In Minas Gerais, this is not the case. Participant observation and interviews revealed that EISs are reviewed only and always by internal staff of the environmental authority. Additionally, the number of people involved in the review is also very different. The content analysis of the EIS review reports, whose full results are presented in Table 2, indicated that in APA, EISs were reviewed by an average of 10 people with different technical backgrounds. In Minas Gerais, an average of three internal analysts, including someone from the legal department, were found to be in charge of reviewing EIS reports. Another contrast between the two agencies is that APA always includes a step of EIS public consultations in the review, whereas in SEMAD, public consultations are required mainly in the licensing of large, potentially impactful projects.

Overall, these findings show that, although following similar institutional arrangements and broad procedural steps, APA has a more open, participative, and interdisciplinary review than SEMAD. APA's approach mirrors more clearly some of the EIS review good practices highlighted in the literature $[26,27,49]$. The superior number of people and interdisciplinary expertise in APA's EIS review process also suggests that the Portuguese agency has a more critical and potentially consistent approach to ensuring quality information in decision making. After all, as Peterson [17] found in his empirical comparison of group versus individual EIS review, " (... ) group assessment is more critical than the individual assessment. This possibly results from a wider technical expertise and balancing of subjective values and perspectives among group members" (p. 169).

\subsection{Procedures and Information Inputs}

The participant observations and content analysis of EIS review reports have helped to reveal procedures and information inputs in the review process in both APA and SEMAD that are not explicit in regulations, particularly in the case of Minas Gerais. The Portuguese review process, as shown in Figure 1, clearly reflects the requirements of the national EIA legislation (DL 151-B/2013 and DL 152-B/2017 revision). The review is structured in two sequential phases: (1) analysis of EIS conformity; and (2) analysis of environmental content conformity. The first phase, as required by law, targets mostly the completeness of EISs. In the second phase, the main purpose is to evaluate the extent to which the document meets content requirements. The review process only advances to the second phase if the EC agrees that the EIS, the respective nontechnical summary and additional information meet minimum quality criteria. To accomplish these tasks, the coordinator of the EIA process, after a preliminary review of the EIS document, invites representatives for an evaluation committee. Once created, the EC starts to evaluate the conformity of the EIS in light of both legislation and EC members' technical preliminary reviews. Then, the process moves to a meeting with the project proponent and/or respective consultants. The EC, if necessary (and that is often the case), can request additional information to complement the EIS document. 

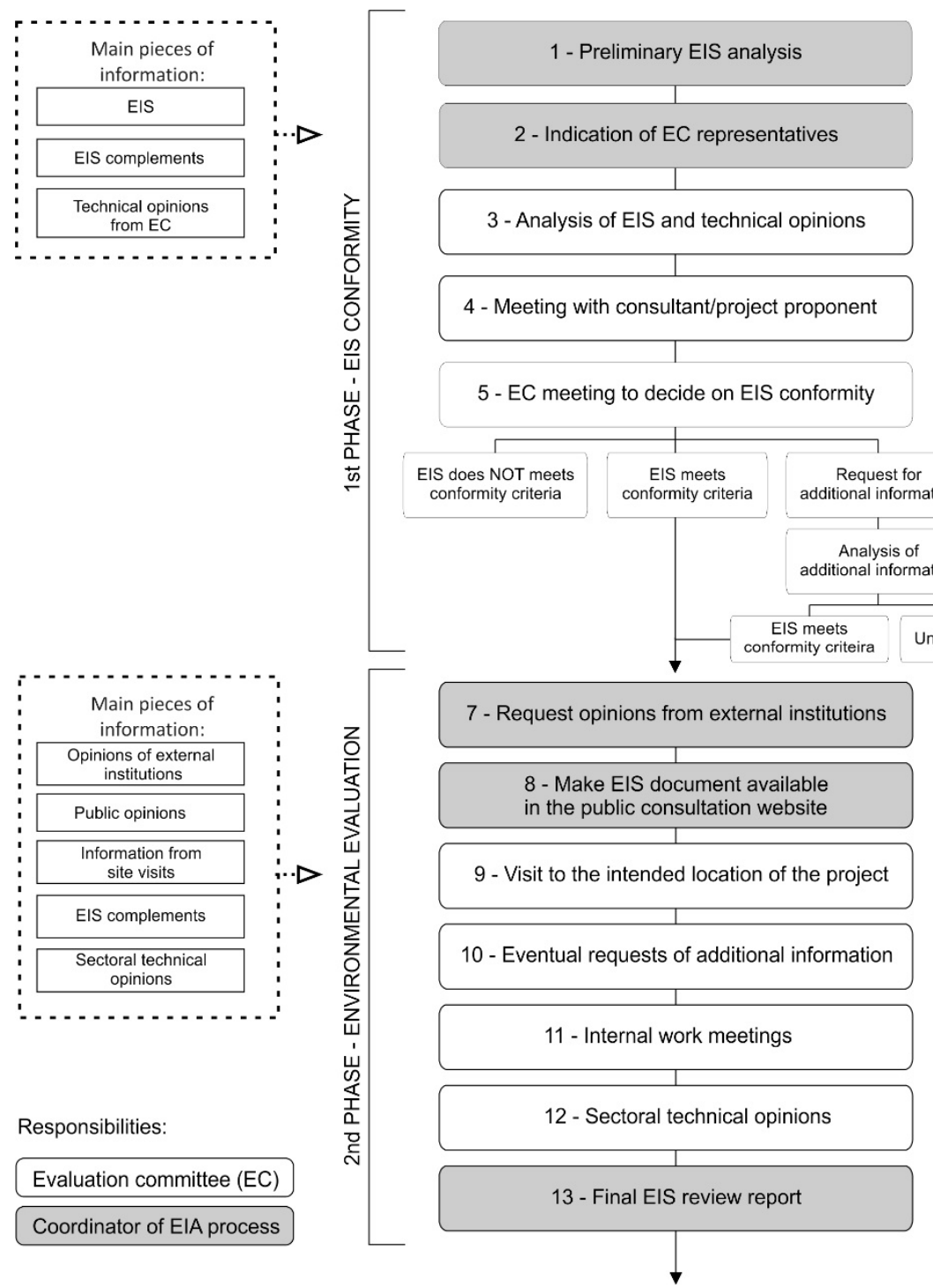

Figure 1. Environmental impact statement (EIS) review procedures and information inputs in the Portuguese Environment Agency (APA, Portugal).

The second phase of the review process in APA starts with the EIA coordinator requesting opinions from external institutions and making the EIS document available for public consultation in the government website. Following that, members of the EC conduct technical visits to the site where the project is to be located. Based on findings from reviews, site inspection, and collected opinions, the EC may request further information from the proponent. A number of internal meetings are held to discuss and reach consensus over the environmental evaluation of the project, in light of all collected information. Finally, the coordinator of the EIA process puts together all the information and makes it available in an EIS review report, which is forwarded for final decision.

In Minas Gerais, the EIS review follows a similar logic, but with some important differences. As shown in Figure 2, in SEMAD, the EIA coordinator, usually a branch manager, is in charge of assigning internal staff to the review. The number of people assigned to this task is frequently limited in number and technical expertise. A particular reviewer is often required to evaluate several knowledge areas that are not related to his or her academic background. Reviewers will then carry out a site visit on the intended location of the project (for pre-approval licensing processes) or on the operating enterprise (for corrective licensing processes). Eventually, SEMAD staff holds meetings with project proponent and respective consultants. When conditions from DN COPAM 225/2018 are met, the review 
may include a step of EIS public consultation, which, in Minas Gerais, takes the form of public hearings. In internal meetings, SEMAD will decide whether additional EIS information is needed from proponents. Finally, in light of collected opinions and the results of the review of the EIS document and respective information complements, the review staff, led by the EIA coordinator, will write a final EIS review report, which is forwarded for final decision.

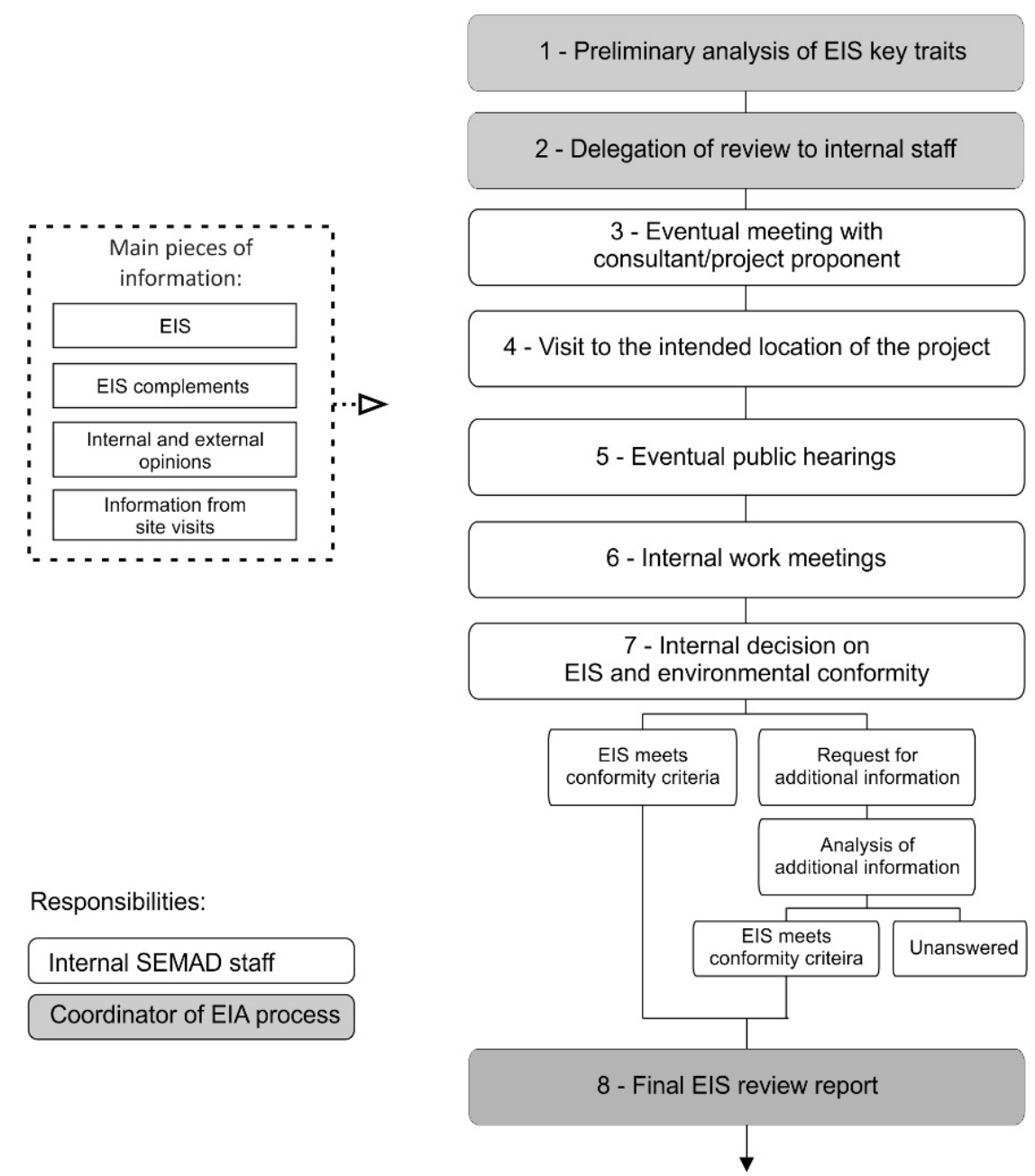

Figure 2. EIS review procedures and information inputs in the State Secretariat for Environment and Sustainable Development (SEMAD, Minas Gerais, Brazil).

The differences between the APA and SEMAD procedures are more easily perceived when one compares Figures 1 and 2. In Portugal, the review process is phased into, first, a verification of information completeness and, second, a verification of content quality. Moreover, the process has more inputs of information from internal and external organizations and more procedural transparency. In Minas Gerais, the whole review process is conducted by a limited number of internal staff without participation from external organizations. The only opportunity for external public input takes place in eventual public hearings.

\subsection{Comparative Analysis of EIS Review Reports}

Findings from the content analysis, presented in Table 2, revealed the extent to which each of the 12 EIS review reports met the list of 15 criteria. Such findings should be carefully considered because they are not judging 'quality' in the review process. They reveal degrees of information disclosure. A review report with high counts of information disclosure, while more transparent, is not necessarily indicative of the quality of the review. 
Table 2. Explicit and non-explicit contents in EIS review reports from APA and SEMAD.

\begin{tabular}{|c|c|c|c|c|c|c|c|c|c|c|c|c|c|c|}
\hline \multirow{2}{*}{\multicolumn{2}{|c|}{ Analyzed Items }} & \multicolumn{6}{|c|}{ APA } & \multicolumn{7}{|c|}{ SEMAD } \\
\hline & & PT-1 & PT-2 & PT-3 & PT-4 & PT-5 & PT-6 & MG-1 & MG-2 & MG-3 & MG-4 & MG-5 & MG-6 & Total \\
\hline \multirow{2}{*}{ AI1: Participant reviewers } & Does it inform who participated in the review? & 1 & 1 & 1 & 1 & 1 & 1 & 1 & 1 & 1 & 1 & 1 & 1 & 12 \\
\hline & Does it inform the thematic areas of reviewers? & 1 & 1 & 1 & 1 & 1 & 1 & 0 & 0 & 0 & 0 & 0 & 0 & 6 \\
\hline $\begin{array}{l}\text { AI2: Procedures adopted in the } \\
\text { review }\end{array}$ & Does it inform what procedures were used in the review? & 1 & 1 & 1 & 1 & 1 & 1 & 0 & 0 & 0 & 0 & 0 & 0 & 6 \\
\hline AI3: Characterization of the project & Does it inform the characteristics of the project? & 1 & 1 & 1 & 1 & 1 & 1 & 1 & 1 & 1 & 1 & 1 & 1 & 12 \\
\hline AI4: Project alternatives & Does it address the project's locational and/or technological alternatives? & 0 & 0 & 1 & 1 & 1 & 0 & 1 & 1 & 1 & 0 & 0 & 0 & 6 \\
\hline AI5: Affected areas & Does it address the spatial scope of the area to be affected by the project? & 1 & 1 & 1 & 1 & 1 & 1 & 1 & 1 & 1 & 1 & 1 & 1 & 12 \\
\hline \multirow{3}{*}{$\begin{array}{l}\text { AI6: Environmental diagnosis of the } \\
\text { affected area }\end{array}$} & $\begin{array}{l}\text { Does it address the characteristics of the physical environment in the area } \\
\text { of influence of the project? }\end{array}$ & 1 & 1 & 1 & 1 & 1 & 1 & 1 & 0 & 1 & 1 & 0 & 0 & 9 \\
\hline & Does it address the characteristics of the biotic environment? & 1 & 1 & 1 & 1 & 1 & 1 & 1 & 1 & 1 & 1 & 0 & 0 & 10 \\
\hline & Does it address the characteristics of the anthropic environment? & 1 & 1 & 1 & 1 & 1 & 1 & 1 & 0 & 0 & 1 & 0 & 0 & 8 \\
\hline \multirow{2}{*}{$\begin{array}{l}\text { AI7: Identification of social and } \\
\text { environmental impacts }\end{array}$} & Does it address the likely impacts? & 1 & 1 & 1 & 1 & 1 & 1 & 1 & 1 & 1 & 1 & 1 & 1 & 12 \\
\hline & Does it address the positive impacts? & 1 & 1 & 1 & 1 & 1 & 1 & 1 & 0 & 1 & 0 & 1 & 0 & 9 \\
\hline \multirow{4}{*}{$\begin{array}{l}\text { AI8: Prediction of magnitude of } \\
\text { impacts }\end{array}$} & Does it address the methods used to forecast impacts? & 0 & 0 & 0 & 0 & 0 & 0 & 0 & 0 & 0 & 0 & 0 & 0 & 0 \\
\hline & Does it address the justification for methodological choices? & 0 & 0 & 0 & 0 & 0 & 0 & 0 & 0 & 0 & 0 & 0 & 0 & 0 \\
\hline & Does it address the indicators used? & 0 & 0 & 0 & 0 & 0 & 0 & 0 & 0 & 0 & 0 & 0 & 0 & 0 \\
\hline & Does it analyze the forecast? & 1 & 1 & 1 & 1 & 1 & 1 & 0 & 1 & 1 & 0 & 0 & 0 & 8 \\
\hline \multirow{2}{*}{$\begin{array}{l}\text { AI9: Assessment of the importance } \\
\text { of impacts }\end{array}$} & $\begin{array}{l}\text { Does it address the impact assessment methodology used to evaluate } \\
\text { importance? }\end{array}$ & 0 & 1 & 1 & 1 & 1 & 1 & 0 & 0 & 1 & 0 & 0 & 0 & 6 \\
\hline & Does it address the impacts considered important? & 1 & 1 & 1 & 1 & 1 & 1 & 1 & 0 & 1 & 0 & 0 & 0 & 8 \\
\hline $\begin{array}{l}\text { AI10: Measures taken for negative } \\
\text { impacts }\end{array}$ & Does it address mitigation measures? & 1 & 1 & 1 & 1 & 1 & 1 & 1 & 1 & 1 & 1 & 1 & 1 & 12 \\
\hline $\begin{array}{l}\text { AI11: Programs to monitor positive } \\
\text { and negative impacts }\end{array}$ & Does it address monitoring programs? & 1 & 1 & 1 & 1 & 1 & 1 & 1 & 1 & 1 & 1 & 1 & 0 & 11 \\
\hline AI12: Public participation & Does it address on the outcomes of public participation? & 1 & 1 & 1 & 1 & 1 & 1 & 0 & 0 & 0 & 0 & 0 & 0 & 6 \\
\hline AI13: Related legal regimes & Does it address legal regimes linked to the EIA process? & 1 & 1 & 1 & 1 & 1 & 1 & 0 & 1 & 1 & 1 & 1 & 1 & 11 \\
\hline $\begin{array}{l}\text { AI14: Relevant Stakeholder } \\
\text { Institutions }\end{array}$ & $\begin{array}{c}\text { Does it address the opinion of other institutions involved in the EIA } \\
\text { process? }\end{array}$ & 1 & 1 & 1 & 1 & 1 & 1 & 1 & 1 & 0 & 0 & 0 & 0 & 8 \\
\hline \multirow[t]{3}{*}{ AI15: Final Recommendation } & $\begin{array}{l}\text { Does it recommend a final decision as to whether or not the project } \\
\text { should proceed? }\end{array}$ & 1 & 1 & 1 & 1 & 1 & 1 & 1 & 1 & 1 & 1 & 1 & 1 & 12 \\
\hline & Does it justify the final recommendation? & 1 & 1 & 1 & 1 & 1 & 1 & 0 & 0 & 0 & 0 & 0 & 0 & 6 \\
\hline & Total & 19 & 20 & 21 & 21 & 21 & 20 & 14 & 12 & 15 & 11 & 9 & 7 & \\
\hline
\end{tabular}


The explicit contents found in the sample 12 EIS review reports helped to understand the scope of the review and its likely effects in decision making. Review reports, as shown in Figure 3, do not provide a balanced account of EIS content. They tend to emphasize particular topics, such as project characteristics, affected areas, and mitigation measures. Some issues of the EIS report, such as prediction of magnitude, were not found to be clearly communicated by reviewers.

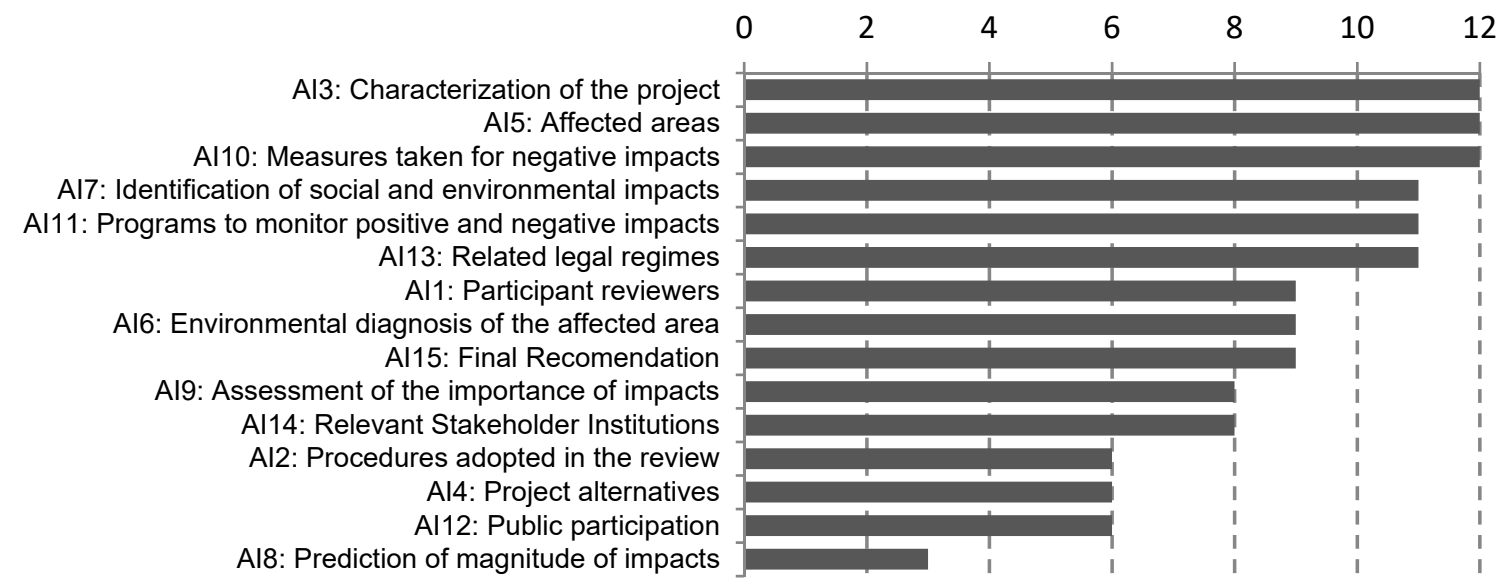

Figure 3. Counts of explicit checklist content items in the sample of EIS review reports.

Differences in information disclosure were found to be very different between APA's and SEMAD's review reports. This was expected because, as previously shown in Table 1, the average size of APA's review reports (132 pages) is 5 times larger than the average size of SEMAD's Reports (26 pages), a fact that suggests that the Portuguese agency tends to be more transparent and disclose more information about the review process. As shown in Figure 4, APA's reports disclosed, on average, $85 \%$ of the checklist items, whereas SEMAD disclosed $47 \%$.

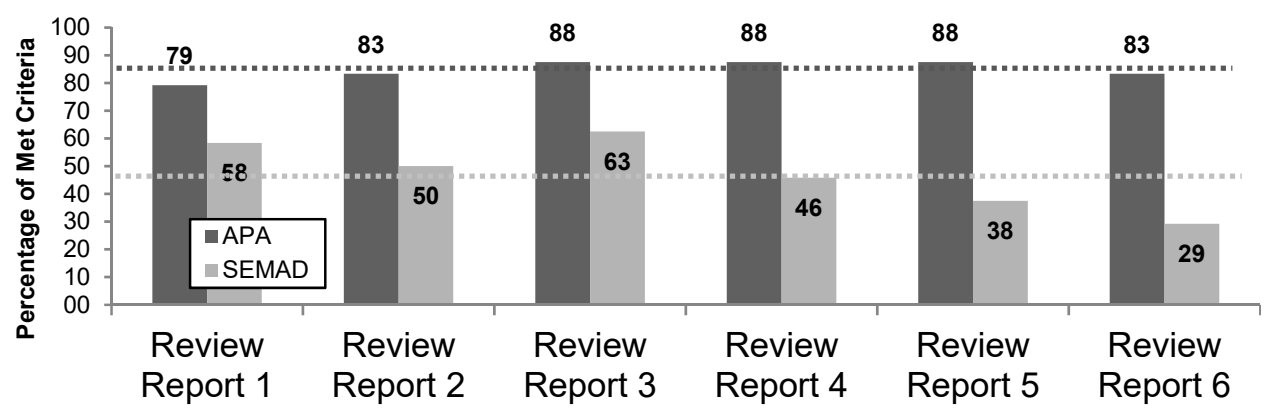

Figure 4. Percentage of explicit contents in EIS review reports: APA versus SEMAD.

More important than these quantitative contrasts are the qualitative differences between the agencies' review reports. Overall, the Portuguese review reports provide a profoundly more detailed account of the procedures, scope, and criteria considered in the review process. For example, APA, like SEMAD, discloses the reviewers involved the process, but APA goes a step further to explain the thematic expertise of each reviewer. APA's reports have specific chapters devoted to explaining the review process, whereas in SEMAD, the explanation is either non-existent or confusingly dispersed in the review report. Considerations of public participation were found in all six review reports of the Portuguese agency. In Minas Gerais, there were no mentions of public participation.

One of the most interesting findings of the content analysis is related to the final recommendation of the review processes. Each of the 12 review reports analyzed here recommended decision-makers to be favorable, with conditions, to the proposals. None of the reports recommended a rejection. The SEMAD reports did not explain how or why they recommended approvals. However, the APA 
review reports not only justified their recommendations, but in 5 out of the 6 documents, they based their recommendations on a quantitative weighted index of environmental impacts, which was a legal requirement of DL 151-B/2013. By doing so, APA reviewers carried out a quantitative and comparative analysis of 'trade-offs' of impacts, an issue that "lies at the heart of environmental impact assessment" [50] (p. 13). While important, particularly in sustainability-oriented processes [51,52], trade-off evaluations tend to be overlooked or poorly understood in the decision-making process. This might suggest that APA's reports are 'better' than SEMAD's. From a transparency standpoint, this is certainly the case. However, from a technical point of view, this will depend on the robustness of the weighted index used during the review. Interestingly, the revised DL 152-B/2017, which transposed the Directive 2014/52/EU, is no longer requiring an 'index'. This suggests that the former practice, captured in this article, might have been perceived as having undesirable effects in decision making. Future studies should follow up on this regulatory change.

\section{Conclusions}

This study evaluated the responsibilities, procedures, information inputs, and scope of EIS review within two environmental authorities: APA, in Portugal, and SEMAD, in the Brazilian state of Minas Gerais. Based on a predominately qualitative methodology informed by participant observation, unstructured interviews, and content analysis, the study has provided what is arguably one of the most detailed characterizations of EIS review to date. Although following a similar logic, EIS review was found to be profoundly different in APA and SEMAD. Such differences were only possible to capture by analyzing the details of the review steps that are often presented in simplified ways in the literature. Overall, the Portuguese agency was found to have a more structured, transparent, participative, interdisciplinary, detailed, and grounded EIS review, thus meeting more clearly some of the good practices that are often highlighted in the literature. These findings are likely to be relevant to stakeholders from various countries, as the issues addressed here are commonly found in international practice. Moreover, given its applied nature, findings are likely to be relevant not only to scholars but also to practitioners, civil servants, and law and policy-makers.

The causes of the differences in EIS review found here are unclear. Future studies should further evaluate whether Portugal is benefiting from being a European Union member and thus having the opportunity to learn from the plurality of practices within the union, or if Portugal has a particular administrative culture that fosters good reviewing practices. Future studies should also evaluate whether findings related to SEMAD are restricted to the Minas Gerais state or mirror a broader situation in Brazil. If the latter is the case, then there is a clear opportunity for capacity-building in that country, something that has long been emphasized in the literature [53].

Regardless of the causes of such differences, this study has helped to expose the relevance of better studying the EIS review process. Small details related to reviewers' independence, public consultations, and trade-off criteria, among others, are expected to affect perceptions around the legitimacy and reliability of recommendations. These details might be influencing not only perceptions, but actual decisions and related consequences to society and the environment. Therefore, it is fundamental that scholars start to go beyond the description of the review process to understand its actual implications to EIA effectiveness.

Author Contributions: Conceptualization, C.F.R., T.B.R. and A.F.; methodological design, C.F.R., T.B.R. and A.F.; data collection and investigation, C.F.R.; writing of first draft, C.F.R.; translation to the English language, A.F.; figures and tables, C.F.R. and A.F.; revisions and final approval of manuscript, C.F.R., T.B.R. and A.F.

Funding: Part of this research was conducted during an international scholarship (PDSE) supported by CAPES Brazilian Federal Agency for Support and Evaluation of Graduate Education within the Ministry of Education of Brazil. The study was also partly funded by the Brazilian National Council for Scientific and Technological Development (CNPq), grant number 311201/2018-0. CENSE is financed by Fundação para a Ciência e Tecnologia, I.P., Portugal (UID/AMB/04085/2019); this funding source played no part in the design, analysis, interpretation, or writing-up of the paper or in the decision to publish. 
Acknowledgments: The authors are grateful to all interviewees and agencies employees for sharing their knowledge and experience. They are also grateful to the various colleagues in SEMAD, CENSE, and UFOP. The first author is particularly grateful to Hugo Rodrigues de Araújo, for his kind and profound help in several stages of this study.

Conflicts of Interest: The authors declare no conflict of interest.

\section{References}

1. Bond, A.; Pope, J. Editorial: The state of the art of impact assessment in 2012. Impact Assess. Proj. Apprais. 2012, 30, 1-4. [CrossRef]

2. IAIA. What Is Impact Assessment? International Association for Impact Assessment (IAIA): Fargo, ND, USA, 2009.

3. Morrison-Saunders, A. Advanced Introduction to Environmental Impact Assessment; Edward Elgar Publishing: Cheltenham, UK, 2018.

4. Morgan, R.K. Environmental impact assessment: The state of the art. Impact Assess. Proj. Apprais. 2012, 30, 5-14. [CrossRef]

5. Lawrence, D.P. Impact Assessment: Practical Solutions to Recurrent Problems and Contemporary Challenges; John Wiley \& Sons: Hoboken, NJ, USA, 2013.

6. Wood, C. Environmental Impact Assessment: A Comparative Review; Pretice Hall: Harlow, UK, 2003.

7. Pope, J.; Bond, A.; Morrison-Saunders, A.; Retief, F. Advancing the theory and practice of impact assessment: Setting the research agenda. Environ. Impact Assess. Rev. 2013, 41,1-9. [CrossRef]

8. Morrison-Saunders, A.; Pope, J.; Gunn, J.A.E.; Bond, A.; Retief, F. Strengthening impact assessment: A call for integration and focus. Impact Assess. Proj. Apprais. 2014, 32, 2-8. [CrossRef]

9. Fischer, T.B.; Noble, B. Impact Assessment Research-Achievements, Gaps and Future Directions. J. Environ. Assess. Policy Manag. 2015, 17, 1501001. [CrossRef]

10. Retief, F. The evolution of environmental assessment debates: Critical perspectives from South Africa. J. Environ. Assess. Policy Manag. 2010, 12, 375-397. [CrossRef]

11. Lee, N.; Colley, R. Reviewing the Quality of Environmental Statements; Occasional Paper Number 24; University of Manchester: Manchester, UK, 1992.

12. Cooper, L.M.; Sheate, W.R. Cumulative effects assessment: A review of UK environmental impact statements. Environ. Impact Assess. Rev. 2002, 22, 415-439. [CrossRef]

13. Landim, S.N.T.; Sánchez, L.E. The contents and scope of environmental impact statements: How do they evolve over time? Impact Assess. Proj. Apprais. 2012, 30, 217-228. [CrossRef]

14. Lee, N.; Brown, D. Quality control in environmental assessment. Proj. Apprais. 1992, 7, 41-45. [CrossRef]

15. Anifowose, B.; Lawler, D.M.; van der Horst, D.; Chapman, L. A systematic quality assessment of Environmental Impact Statements in the oil and gas industry. Sci. Total Environ. 2016, 572, 570-585. [CrossRef]

16. Lima, L.H.; Magrini, A. The Brazilian Audit Tribunal's role in improving the federal environmental licensing process. Environ. Impact Assess. Rev. 2010, 30, 108-115. [CrossRef]

17. Peterson, K. Quality of environmental impact statements and variability of scrutiny by reviewers. Environ. Impact Assess. Rev. 2010, 30, 169-176. [CrossRef]

18. Bond, A.J.; Viegas, C.V.; Coelho, C.C.; Selig, P.M. Informal knowledge processes: The underpinning for sustainability outcomes in EIA? J. Clean. Prod. 2010, 18, 6-13. [CrossRef]

19. Sánchez, L.E.; André, P. Knowledge management in environmental impact assessment agencies: A study in Québec, Canada. J. Environ. Assess. Policy Manag. 2013, 15, 1350015. [CrossRef]

20. Cashmore, $\mathrm{M}$. The role of science in environmental impact assessment: Process and procedure versus purpose in the development of theory. Environ. Impact Assess. Rev. 2004, 24, 403-426. [CrossRef]

21. Willis, K.G. Judging Development Control Decisions. Urban Stud. 1995, 32, 1065-1079. [CrossRef]

22. Lim, G.-C. Theory and Practice of EIA Implementation: A Comparative Study of Three Developing Countries. Environ. Impact Assess. Rev. 1985, 5, 133-153. [CrossRef]

23. Advisian. International Review of Environmental Assessment Processes; Advisian: Calgary, AB, Canada, 2016.

24. Glasson, J.; Salvador, N.N. EIA in Brazil: A procedures-practice gap. A comparative study with reference to the European Union, and especially the UK. Environ. Impact Assess. Rev. 2000, 20, 191-225. [CrossRef] 
25. Ross, W.A. Evaluating environmental impact statements. J. Environ. Manag. 1987, 25, 137-147.

26. Senécal, P.; Goldsmith, B.; Conover, S.; Sadler, B.; Brown, K. Principles of Environmental Impact Assessment Best Practice. Available online: http://www.iaia.org/publicdocuments/special-publications/Principles\%20of $\%$ 20IA_web.pdf (accessed on 20 January 2011).

27. Sadler, B. Environmental Assessment in a Changing World: Evaluating Practice to Improve Performance; Canadian Environmental Assessment Agency (CEAA): Ottawa, ON, Canada; International Association for Impact Assessment (IAIA): Ottawa, ON, Canada, 1996.

28. NCEA. Review in EIA: Memorandum by the NCEA-Part of a Three Year Co-Operation Project on EIA between the Burundi Ministry for Water, Environment, Urbanism and Spatial Planning (MEEATU) and the NCEA; Netherlands Commission for Environmental Assessment (NCEA): Utrecht, The Netherlands, 2012.

29. Morrison-Saunders, A.; Bailey, J. Transparency in environment impact assessment decision-making: Recent developments in Western Australia. Impact Assess. Proj. Apprais. 2000, 18, 260-270. [CrossRef]

30. Thomas, I.; Elliot, M. Environmental Impact Assessment in Australia: Theory E Practice; The Federation Press: Annandale, VA, USA, 2005.

31. Glasson, J.; Therivel, R.; Chadwick, A. Introduction to Environmental Impact Assessment; Routledge: London, UK; New York, NY, USA, 2005.

32. Mwalyosi, R.; Hughes, R.; Howlett, D. Orientation Course on Environmental Impact Assessment in Tanzania Resource Handbook; International Institute for Environment and Development: London, UK, 1999.

33. Günther, M.; Geißler, G.; Köppel, J. Many roads may lead to Rome: Selected features of quality control within environmental assessment systems in the US, NL, CA, and UK. Environ. Impact Assess. Rev. 2017, 62, 250-258. [CrossRef]

34. Morgan, R.K. Environmental Impact Assessment: A Methodological Approach; Springer: Norwell, MA, USA, 1998.

35. Creswell, J.W. Qualitative Inquiry E Research Design: Choosing Among Five Approaches; SAGE Publications: Thousand Oaks, CA, USA, 2007.

36. Yin, R.K. Case Study Research: Design and Methods; SAGE Publications: Thousand Oaks, CA, USA, 2003.

37. Given, L.M. The SAGE Encyclopedia of Qualitative Research Methods: Volumes 1 \& 2; SAGE Publications: Thousand Oaks, CA, USA, 2008.

38. Babbie, E. The Practice of Social Research; Cengage Learning: Wadsworth, OH, USA, 2013.

39. Krippendorff, K. Content Analysis: An Introduction to Its Methodology; SAGE Publications: Thousand Oaks, CA, USA, 2004.

40. European Union. Directive 2011/92/EU of the European Parliament and of the Council of 13 December 2011 on the Assessment of the Effects of Certain Public and Private Projects on the Environment; European Parliament and of the Council: Brussels, Belgium, 2012.

41. Ramos, T.B.; Mascarenhas, A.; Polido, A. Challenges and opportunities for the revised EIA Directive implementation in Portugal. UVP Rep. 2016, 30, 82-87.

42. Sánchez, L.E. Development of Environmental Impact Assessment in Brazil. UVP Rep. 2013, 27, $193-200$.

43. Moreira, I.V. EIA in Latin America. In Environmental Impact Assessment: Theory and Practice; Wathern, P., Ed.; Routledge: London, UK; New York, NY, USA, 1988; pp. 239-253.

44. Brazil, Lei No 6938, de 31 de agosto de 1981. Dispõe Sobre a Política Nacional do Meio Ambiente, Seus Fins e Mecanismos de Formulação e Aplicação, e dá Outras Providências; Presidência da República, Casa Civil, Subchefia para Assuntos Jurídicos: Brasília, Brazil, 1981. Available online: http://www.planalto.gov.br/ccivil_03/leis/ 16938.htm (accessed on 11 June 2019).

45. CONAMA. Resolução CONAMA No 001/1986-Dispõe Sobre Critérios Básicos e Diretrizes Gerais Para o Relatório de Impacto Ambiental—RIMA; Conselho Nacional do Meio Ambiente (CONAMA): Brasília, Brazil, 1986.

46. CONAMA. Resolução CONAMA N² 237/1997-Regulamenta os Aspectos de Licenciamento Ambiental Estabelecidos na Política Nacional do Meio Ambiente; Conselho Nacional do Meio Ambiente (CONAMA): Brasília, Brazil, 1997.

47. Fonseca, A.; Rodrigues, S.E. The attractive concept of simplicity in environmental impact assessment: Perceptions of outcomes in southeastern Brazil. Environ. Impact Assess. Rev. 2017, 67 (Suppl. C), 101-108. [CrossRef]

48. Garcia, L.C.; Fonseca, A. The use of administrative sanctions to prevent environmental damage in impact assessment follow-ups. J. Environ. Manag. 2018, 219, 46-55. [CrossRef]

49. European Comission. Guidance on EIA-EIS Review; European Comission: Luxembourg, 2001. 
50. Retief, F.; Morrison-Saunders, A.; Geneletti, D.; Pope, J. Exploring the psychology of trade-off decision-making in environmental impact assessment. Impact Assess. Proj. Apprais. 2013, 31, 13-23. [CrossRef]

51. Gibson, R.B. Sustainability assessment: Basic components of a practical approach. Impact Assess. Proj. Apprais. 2006, 24, 170-182. [CrossRef]

52. Morrison-Saunders, A.; Pope, J. Conceptualising and managing trade-offs in sustainability assessment. Environ. Impact Assess. Rev. 2013, 38, 54-63. [CrossRef]

53. Kirchhoff, D. Capacity building for EIA in Brazil: Preliminary considerations and problems to be overcome. J. Environ. Assess. Policy Manag. 2006, 8, 1-18. [CrossRef]

(C) 2019 by the authors. Licensee MDPI, Basel, Switzerland. This article is an open access article distributed under the terms and conditions of the Creative Commons Attribution (CC BY) license (http://creativecommons.org/licenses/by/4.0/). 